\title{
João Carlos Teixeira Brandão, the first Brazilian professor of Psychiatry
}

João Carlos Teixeira Brandão, o primeiro professor brasileiro de Psiquiatria

Cátia Mathias ${ }^{1}$, Antonio E. Nardi ${ }^{1}$

\begin{abstract}
Aim: To describe the highlights in the personal, professional, and political life of the first Brazilian Professor of Psychiatry. Methods: The article draws on a wide range of documents: newspaper articles, documents of Brazilian medical institutions, scientific articles, theses, and books. Results: João Carlos Teixeira Brandão was a distinguished $19^{\text {th }}$-century Brazilian psychiatrist and leader of the institutionalization and consolidation of the field of Psychiatry in Brazil. He contributed to the recognition of the professional jurisdiction of the "alienist", a specialized professional, qualified in clinical practice, diagnosis, and the definition of the boundaries between sanity and madness, based on scientific criteria, in the late $19^{\text {th }}$ and early $20^{\text {th }}$ centuries. Conclusion: This article highlights the key moments in the professional and political career of Professor João Carlos Teixeira Brandão, from his graduation from the Rio de Janeiro School of Medicine in 1877 to his death in 1921, when he was still active in national politics.
\end{abstract}

Keywords: Psychiatry; mental disorders, history of Medicine.

\section{RESUMO}

Descrever os principais pontos da vida pessoal, profissional e política do primeiro professor brasileiro de Psiquiatria. Métodos: Todas as fontes de documentos - artigos de jornais, documentos das instituições médicas brasileiras, artigos médicos, teses e livros. Resultados: João Carlos Teixeira Brandão foi um ilustre psiquiatra brasileiro do século XIX e líder da institucionalização e consolidação do campo de Psiquiatria no Brasil. Contribuiu para o reconhecimento da jurisdição profissional do “alienista”, um profissional especializado, qualificado em prática clínica, diagnóstico e definição dos limites entre sanidade e loucura, com base em critérios científicos, no final do século XIX e início do século XX. Conclusões: Este artigo destaca os momentos-chave da carreira profissional e política do professor João Carlos Teixeira Brandão, desde sua graduação na Faculdade de Medicina do Rio de Janeiro em 1877 até sua morte em 1921, enquanto ainda atuava na política nacional.

Palavras-chave: Psiquiatria; transtornos mentais; história da Medicina.

João Carlos Teixeira Brandão was a distinguished $19^{\text {th }}$-century Brazilian psychiatrist and leader of the institutionalization and consolidation of Brazilian Psychiatry. He helped to disseminate appropriate and adapted techniques and practices from French alienism ("Psychiatry") for Brazil's National Asylum for the Alienated (Hospicio Nacional de Alienados) and the Pavilion for Clinical Observation ${ }^{1}$. This article discusses the highlights in the professional and political career of João Carlos Teixeira Brandão, from his graduation from the Rio de Janeiro School of Medicine in 1877 until his death in 1921.

\section{THE CLINICAL PSYCHIATRY CHAIR AT THE RIO DE JANEIRO SCHOOL OF MEDICINE}

João Carlos Teixeira Brandão was born on December 28, 1854, son of the notary public and farmer Felício Viriato
Brandão and Maria Flora Teixeira, in Arraial de São Sebastião, São João Marcos, Brazil. He did his undergraduate studies at the Dom Pedro II Imperial College, where he graduated in science and literature, and enrolled in the Rio de Janeiro School of Medicine in 1872. He graduated in Medicine in 1877, after defending his thesis in surgery entitled "Operations required by narrowing of the urethra; on the quinines; optimal treatment of accidental and surgical wounds; organic lesions of the heart".

Teixeira Brandão began his medical career in Barra Mansa, in the State of Rio de Janeiro. João Vicente Torres Homem (1837-1887), Professor of the First Chair of Clinical Medicine at the Rio de Janeiro School of Medicine and friend and former professor of Teixeira Brandão, encouraged him to pursue a specialization in alienism in Europe in 1880, even providing him with financial assistance ${ }^{2}$. Although alienism was considered a lesser branch of Medicine at the time, the fact that there was no specialist in Brazil offered the opportunity

'Universidade Federal do Rio de Janeiro, Intituto de Psiquiatria, Rio de Janeiro RJ, Brasil.

Correspondence: Antonio E Nardi; Instituto de Psiquiatria da Universidade Federal do Rio de Janeiro; Rua Visconde de Pirajá, 407/702; $22410-003$ Rio de Janeiro RJ, Brasil; E-mail: antonioenardi@gmail.com

Conflict of interest: There is no conflict of interest to declare.

Received 24 November 2017; Received in final form 12 June 2018; Accepted 11 July 2018. 
of social promotion and scientific recognition for a physician aspiring to acquire knowledge and practice in the implementation of this new theoretical and practical field ${ }^{2}$.

The first Chair in Clinical Psychiatry in Brazil was created in 1881, and was considered a milestone in the process of medicalization of mental illness in the country. The practical part of the course on Clinical Psychiatry and Diseases of the Nervous System at the Rio de Janeiro School of Medicine was administered at the Dom Pedro II Asylum, as the new chair lacked a teaching hospital of its own ${ }^{3,4}$. Although the new chair was considered a step forward in medical training, it lacked its own autonomous space for practical classes. In 1883, a public admissions test was announced to fill the seat of Professor of Clinical Psychiatry of the Rio de Janeiro School of Medicine, and Teixeira Brandão was thus sworn in as the first Brazilian Professor of Clinical Psychiatry on April 25, 1883.

The history of Brazilian Neurology and Psychiatry dates back to 1831, when the first articles on these specialties were published ${ }^{5}$. These two branches of Medicine were both formed in Brazil around the National Hospice for the Insane ${ }^{4,5}$. It should be noted that the Chair of Clinical Psychiatry and Nervous Disorders, created in 1881, integrated the specialties of Psychiatry and Neurology, and Teixeira Brandão was responsible for teaching both courses at the School of Medicine of Rio de Janeiro ${ }^{5}$. The division of the chair materialized in 1912, and although Teixeira Brandão was against this measure, Antonio Austregésilo was installed as Professor of Neurology. These developments provided the background for the influential and pioneering School of Psychiatry and Neurology in Brazil ${ }^{5}$.

During the time that Teixeira Brandão chaired the course in Clinical Psychiatry at the Rio de Janeiro School of Medicine, the classes were based on French alienism. Teixeira Brandão "succeeded in interesting some students in the field of Psychiatry", forming a group with his pupils that psychiatrist and Professor Raimundo Nina Rodrigues (1862-1906) (.5 $^{4}$ referred to as "a school of Psychiatry in Rio de Janeiro".

In Rio de Janeiro, Teixeira Brandão was elected to the Imperial Academy of Medicine in 1886, where he presented the treatise entitled "Fixed Ideas, Genesis, and Nosological Classification". He became an emeritus member of the Imperial Academy in 1918 (Figure 1). In 1897, he helped found the Society of Medical and Anthropological Jurisprudence at a meeting convened in the Pavilion for Clinical Observation ${ }^{1}$ and was elected its president. That same year, the Society began to publish the Archives of Medical and Anthropological Jurisprudence.

In addition to having produced scientific articles and Psychiatry books in Portuguese, according to Engel ${ }^{3}$ "Teixeira Brandão was the first to propose a sophisticated classification of mental illnesses, which would have a major influence on his young students."

In 1886, he published the report The Alienated in Brazil, which he submitted to the Minister of the Empire of Brazil, João Maurício Wanderley, the Baron of Cotegipe (1815-1889).
The report denounced the dire conditions of psychiatric patients in Brazil and called for a reform to make their condition more humane, especially through laws to protect their rights. The following year, the Rio de Janeiro Mercy Hospital (Santa Casa de Misericórdia) established a commission, of which Teixeira Brandão was a member, to investigate the causes for the rise in deaths of patients in the Dom Pedro II Asylum. Teixeira Brandão's title as specialist, further legitimized by his Chair in Clinical Psychiatry at the School of Medicine, probably encouraged the support his critiques received from the Baron of Cotegipe and the Diário Official, the newspaper that was considered the official communications vehicle of the monarchy $y^{6,7}$.

In 1890, Teixeira Brandão was named director of the newly-created Medical Care and Legal Aid Service for the Alienated. That same year, the Brazilian government separated the Dom Pedro II Asylum (renamed the National Asylum for the Alienated, following the proclamation of the Republic in 1889) from the Rio de Janeiro Mercy Hospital'.

Teixeira Brandão reported to the Minister of Domestic Affairs, in 1891, that police authorities were sending mentally ill individuals to the Beggars' Asylum. From there they were transferred to the National Asylum for the Alienated, with no identification, background, or information on causes of their purported illness. Based on this proposal, the Pavilion for Clinical Observation for Medical Care and Legal Aid for the Alienated was created in $1892^{1}$.

In 1892, Teixeira Brandão published his Instructions for the Internal Services of the National Asylum for the Alienated, to organize the hospital's activities. The fact that the asylum was now under federal jurisdiction increased the number of admissions, as everyone requiring specialized care was sent there, especially individuals who might disturb the peace,

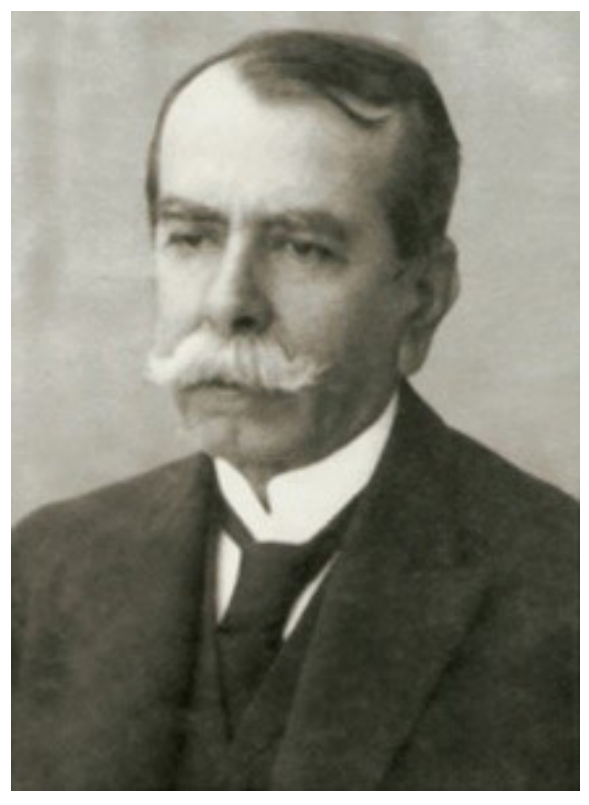

Figure 1. Professor João Carlos Teixeira Brandão circa 1918. Photo from the collection of the National Academy of Medicine, Brazil. Reprinted with permission. 


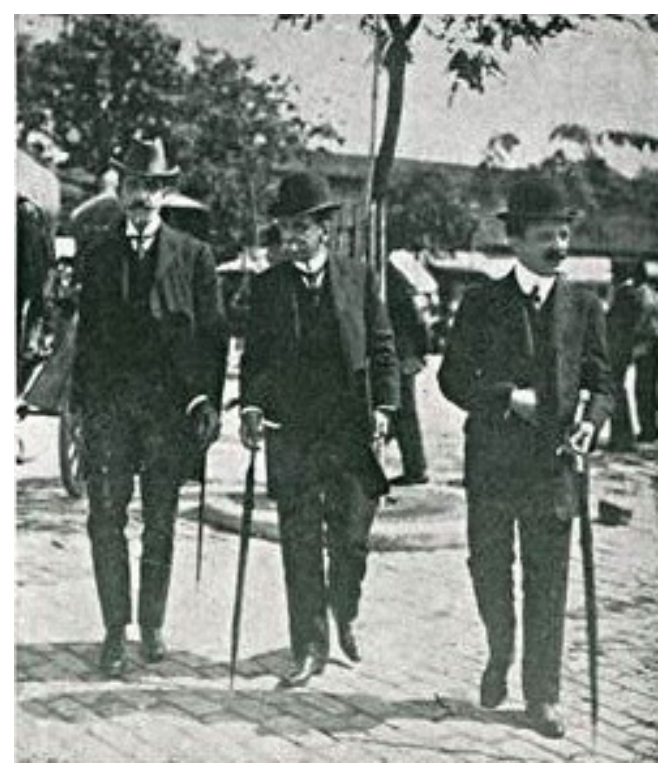

Figure 2. Photo from the newspaper Fon Fon, 1907. Professor João Carlos Teixeira Brandão in the middle. On the left, Carlos Peixoto (1872-1917), lawyer and President of the Brazilian Chamber of Deputies, and on the right, Afrânio Peixoto (1876-1947), Professor of Forensic Medicine at the School of Medicine of Rio de Janeiro and Director of the Office of Forensic Medicine. Photo from the Brazilian Digital Newspaper and Periodicals Library. Reprinted with permission. thus making Psychiatry a tool for social control in late $19^{\text {th }}$ century Brazilian society ${ }^{7}$.

The Gazeta da Tarde newspaper published statistical data comparing the hospital's administration under the Mercy Hospital with Teixeira Brandão's new "scientific administration". He was opposed to hospitalizing criminals, but court orders forced him to admit some of them. According to Engel ${ }^{3}$, Teixeira Brandão was in favor of a specific forensic psychiatric service for the criminally insane (Figure 2), on grounds that they were not ordinary criminals and, therefore, should not be confined either to hospitals or to prisons. But this change only came about in 1921, with the inauguration of the Forensic Asylum in Rio de Janeiro.

\section{CONCLUSION}

Teixeira Brandão was aligned with the profile of the new intellectual of the time. His involvement in various medical, scientific, political, and social issues throughout his intellectual career, outlined and consolidated during the development of psychiatric practice in Brazil, contributed to the consolidation of Psychiatry as a legitimately-acknowledged specialty in Brazilian medicine and society.

\section{References}

1. Mathias C, Verçosa N, Anselmé C, Nardi AE. One hundred and twenty years from the former 'Pavilion for Clinical Observation' to the National Lunatic Asylum, later Institute of Psychiatry - Federal University of Rio de Janeiro. J Med Biogr. 2016 Aug;24(3):376-9. https://doi.org/10.1177/0967772014537741

2. Teixeira MO. Deus e a ciência na terra do sol: o Hospício de Pedro II e a constituição da medicina mental no Brasil [Thesis]. Instituto de Psiquiatria, Universidade Federal do Rio de Janeiro, Rio de Janeiro, RJ, 1998.

3. Engel MG. Os delírios da razão: médicos, loucos e hospícios: Rio de Janeiro, 1830-1930. Rio de Janeiro: Fiocruz; 2001.

4. Nina-Rodrigues R. A paranoia nos negros: estudo clínico e médico legal (1903) parte 1. Rev Latinoam Psicopatol Fundam. 2004;7(2):161-78. https://doi.org/10.1590/1415-47142004002011
5. Gomes MM, Engelhardt E. Historical sketches of the beginnings of the academic "mental and nervous diseases" in Brazil, and European influences. Arq Neuropsiquiatr. 2013 Aug;71(8):562-5. https://doi.org/10.1590/0004-282X20130095

6. Peres MA, Barreira IA, Santos TC, Almeida Filho AJ, Oliveira AB. $O$ ensino da psiquiatria e o poder disciplinar da enfermagem religiosa: o Hospício de Pedro II no segundo reinado. Texto Contexto Enferm. 2011;20(4):700-8. https://doi.org/10.1590/S0104-07072011000400008

7. Teixeira MO, Ramos FA. As origens do alienismo no Brasil: dois artigos pioneiros sobre o Hospício de Pedro II. Rev Latinoam Psicopatol Fundam. 2012;15(2):364-81. https://doi.org/10.1590/S1415-47142012000200011

8. Hospício de alienados. Gazeta da Tarde, 10 jun. 1896. p. 2. 